Rountree, P. M. (1955). J. gen. Microbiol. 12, 275-287

\title{
The Role of Divalent Gations in the Multiplication of Staphylococcal Bacteriophages
}

\author{
BY PHYLLIS M. ROUNTREE \\ Fairfax Institute of Pathology, Royal Prince Alfred Hospital, \\ Sydney, Australia
}

SUMMARY: The staphylococcal typing phages require divalent cations for a stage in phage growth which is probably that of penetration. When phage is adsorbed to the cell surface of sensitive cocci and a chelating agent is added, there is a short period during which the phage particle may be inactivated and its lethal effect on the coccus prevented. Cocci attacked by phages of serological group A show penetration of the phages in distilled water $+\mathrm{CaCl}_{2}$, or $+\mathrm{MgCl}_{2}$, or to a less extent $+\mathrm{SrCl}_{2}$. The phages of group $\mathbf{B}$ are unable to penetrate in presence of $\mathrm{SrCl}_{2}$ and in some cases $\mathrm{MgCl}_{2}$ is only partially active as compared with $\mathrm{CaCl}_{2}$. Ca ions appear to be required specifically at a late stage in phage synthesis since the average yield of phage/coccus increases with increasing concentration of $\mathrm{CaCl}_{2}$; the addition of a chelating agent towards the end of the latent period depresses the yield of phage.

Some bacteriophages require $\mathrm{Ca}$ ions either for adsorption or during phage multiplication. With coliphage T5 (Adams, 1949; Luria \& Steiner, 1954), a typhoid phage (Fildes, Kay \& Joklik, 1953) and lactic streptococcus phages (Potter \& Nelson, 1953) Ca is not necessary for adsorption but apparently acts at an early stage in phage synthesis. Delbrück (1948) and Beumer \& BeumerJochmans (1951) described two phages (a mutant of coliphage T4 and a dysentery phage) which apparently required $\mathrm{Ca}$ for adsorption. However, Fildes (1953) pointed out that in these cases the activity of alternative divalent cations was not investigated and it is therefore uncertain whether or not the $\mathrm{Ca}$ requirements were absolute.

Puck (1953), with coliphages of the $T$ series, produced evidence that there were a number of stages in the process of phage invasion. He suggested that the first step of adsorption involved electrostatic forces which were supplied by cations of the medium and which permitted reversible attachment of phage to cell surface. The next step was the separation of the protein and deoxyribonucleic acid components of the phage; this is quickly followed by a process leading to cell killing, and the penetration of deoxyribonucleic acid into the cell and the initiation of phage synthesis in lytic systems. The process of penetration is probably enzymic in nature. The staphylococcal typing phages (Rountree, 1951) require divalent cations for adsorption; this process is inhibited by Na citrate. Each phage has characteristic cation requirements which are related to the phage rather than to the host cell surface. The present paper deals with the role of divalent cations in the different stages of multiplication of staphylococcal phage which follow the first step of adsorption. 


\section{ME'THODS}

The typing phages of Wilson \& Atkinson (1945) and their respective propagating strains were used. The methods of phage estimation, preparation of glassware and of salt solutions have been previously described (Rountree, 1951). In general, phage counts were made in quadruplicate. Since no chemically defined medium which regularly supported the growth of the phages was available, glucose $(0 \cdot 15 \%, \mathrm{w} / \mathrm{v})$ veal broth was used as basal medium which was supplemented with various cations as required. The disodium salt of ethylene diaminotetra-acetic acid (EDTAA) (supplied by Dr F. Dwyer, University of Sydney) was used as a chelating agent. Na citrate was unsuitable for this purpose since in the concentrations necessary for effective chelation it inactivated many of the phages when they were in the free state.

The agar nutrient broth medium used for plaque counting had $0 \cdot 1 \%(w / v)$ $\mathrm{CaCl}_{2}$ added to it.

\section{RESULTS}

One-step growth curves

Knowledge of the lengths of the minimum latent period and of the one-step growth curve and average burst size were required for the various different phages. One large batch of broth was prepared which supported the growth of all the phages.

The appropriate propagating strain of staphylococcus was grown in broth with aeration in a water bath at $37^{\circ}$ until the total count (determined turbidometrically) reached $1 \times 10^{8}$ cells $/ \mathrm{ml}$. Sufficient phage was then added to give 3-4 particles/cell. After $10 \mathrm{~min}$. of adsorption the infected cells were so diluted in warmed broth that on plating $0.01 \mathrm{ml}$. samples $1-3$ plaques were obtained. Incubation was continued at $37^{\circ}$, samples being removed for plating at $5 \mathrm{~min}$. intervals. The end of the latent period was marked by an increase in the plaque count. If all cells had been infected, the end of the period of phage release was followed by a steady count. The average burst size was obtained by dividing the final phage count calculated in terms of the original volume of infected culture by the number of infected cells.

The phages showed fairly wide differences in the length of the minimum latent period; this ranged from $35 \mathrm{~min}$. for phage $3 \mathrm{~B}$ to $60 \mathrm{~min}$. for phage 42 $\mathrm{B}$ (Table 1). Most of the phages, however, gave their first release of phage between 40 and $50 \mathrm{~min}$. The end of phage release ranged from 50 to $75 \mathrm{~min}$. In this particular batch of broth the average yield of phage particles per cell ranged from 12 for phage $42 B$ to 168 for $47 \mathrm{D}$. Replicate estimations of the average burst size of different phages agreed well, although exact reproduction of results from day to day was not always possible. This was thought to be due chiefly to variability in cell sensitivity. Variation in average burst size also occurred with different batches of broth. 
Table 1. Times of the minimum latent period and the end of phage release of staphylococcal phages grown in broth

\begin{tabular}{|c|c|c|c|}
\hline $\begin{array}{l}\text { Latent } \\
\text { period } \\
\text { (min.) }\end{array}$ & Phages & $\begin{array}{l}\text { End of } \\
\text { phage release } \\
\text { (min.) }\end{array}$ & Phages \\
\hline $35-40$ & $3 \mathrm{~B}, 44 \mathrm{~A}$ & $50-55$ & $47 \mathrm{D}, 51,52 \mathrm{~A}$ \\
\hline \multirow[t]{2}{*}{$40-45$} & $\begin{array}{l}3 \mathrm{C}, 6,7,29,29 \mathrm{~A}, 31 \mathrm{~A}, 31 \mathrm{~B}, \\
42 \mathrm{C}, 44,47 \mathrm{~A}, 47 \mathrm{D}, 51,52, \\
52 \mathrm{~A}\end{array}$ & $55-60$ & $\begin{array}{l}3 \mathrm{C}, 6,7,29 \mathrm{~A}, 31 \mathrm{~A}, 44 \mathrm{~A} \\
47 \mathrm{~A}, 52\end{array}$ \\
\hline & & $60-65$ & $\begin{array}{l}3 \mathrm{~B}, 29,42 \mathrm{C}, 42 \mathrm{D}, 44,47, \\
47 \mathrm{~B}\end{array}$ \\
\hline $45-50$ & $\begin{array}{l}3 \mathrm{~A}, 31,42 \mathrm{D}, 42 \mathrm{E}, 47,47 \mathrm{~B}, \\
47 \mathrm{C}\end{array}$ & $65-70$ & $31,31 \mathrm{~B}, 42 \mathrm{~B}, 42 \mathrm{E}$ \\
\hline $55-60$ & $42 \mathrm{~B}$ & $70-75$ & $3 \mathrm{~A}, \mathbf{4 7 \mathrm { C }}$ \\
\hline
\end{tabular}

\section{Effect of divalent cations on the average burst size}

Williams Smith (1948) observed that the addition of $\mathrm{CaCl}_{2}$ to broth in which staphylococcal phages could not be propagated rendered the medium adequate. This stimulatory effect of $\mathrm{CaCl}_{2}$ might be due solely to its effect on phage adsorption but it seems probable that $\mathrm{Ca}$ ions were required for a later step or steps in phage synthesis. In the present investigations, one particular batch of broth which appeared to be deficient in calcium, since some phages failed to multiply in it but added $\mathrm{CaCl}_{2}$ made it adequate for growth, was used to examine the divalent cation requirements of the phages. Experiments were so arranged that growth tubes contained two to three infected cells $/ 0.01 \mathrm{ml}$. during the latent period and so yielded countable numbers of plaques when plated directly at the end of the rise in free phage. To a series of $6 \times \frac{3}{4}$ in. test tubes (wide tubes to ensure adequate aeration) was added $0 \cdot 1 \mathrm{ml}$. of solutions of either $\mathrm{CaCl}_{2}, \mathrm{MgCl}_{2}$ or $\mathrm{SrCl}_{2} \cdot 6 \mathrm{H}_{2} \mathrm{O}$ to give final salt concentrations of 20 , 50,100 and $200 \mu \mathrm{g} . / \mathrm{ml}$. Samples of young aerated broth culture $(0 \cdot 8 \mathrm{ml}$.) of the appropriate staphylococcus were added to each of the tubes. These were placed in a water-bath at $37^{\circ}$ and then received $0.1 \mathrm{ml}$. of phage suspension (diluted in broth). Control tubes of cells + phage without added salt, and of the phage in broth + salts, were included in each test. Samples were plated during the latent period to determine the number of infected cells and at the end of 70 or 80 min., depending on the growth curve of the particular phage being examined. The average burst size was calculated by dividing the final phage count by the count during the latent period.

All the phages examined showed an increase of the average burst size on addition of $\mathrm{CaCl}_{2}$, but there were differences in the behaviour of different phages which could be correlated with their serological types. Table 2 shows the average burst size obtained for twenty different phages belonging to serological groups A and B (Rountree, 1949). The group A phages were able to establish infection in the basal broth alone and their average burst sizes were, in most cases, of a reasonably high order; however, the addition of $\mathrm{CaCl}_{2}$ increased their burst sizes. The amounts of $\mathrm{CaCl}_{2}$ which gave optimal phage production varied and was $20 \mu \mathrm{g} . / \mathrm{ml}$. with phages $3 \mathrm{C}, 7$ and $51,50 \mu \mathrm{g} . / \mathrm{ml}$. 
with phage 6 , and $100 \mu \mathrm{g} . / \mathrm{ml}$. with the remainder. When $\mathrm{MgCl}_{2}$ or $\mathrm{SrCl}_{2}$ was substituted for $\mathrm{CaCl}_{2}$ no clear-cut evidence of increased yield was obtained. Possible exceptions were phage 6 in which an average burst size of 64 was produced in the presence of $200 \mu \mathrm{g}$. $\mathrm{MgCl}_{2} / \mathrm{ml}$. as compared with 44 in the basal broth, and phage 7 which gave average burst sizes of 16 and 21 in 100 and $200 \mu \mathrm{g}$. $\mathrm{SrCl}_{2} / \mathrm{ml}$. respectively, as compared with 7 in broth alone.

Table 2. Effect of added divalent cations on the average burst size in broth of staphylococcal phages

The phages in the upper half of the table ( $3 \mathrm{~A}$ to 51 inclusive) belong to serological group $A$; those in the lower half (29 to $52 \mathrm{~A}$ inclusive) to serological group $\mathrm{B}$. Average burst size obtained by plating at $70-80 \mathrm{~min}$. after infection, $0=$ disappearance of phage, $1=$ adsorption but no multiplication.

\begin{tabular}{|c|c|c|c|c|c|c|c|c|c|c|c|c|c|}
\hline \multirow[b]{3}{*}{ Phage } & \multirow{3}{*}{$\begin{array}{l}\text { Broth } \\
\text { alone }\end{array}$} & \multicolumn{12}{|c|}{ Composition of broth + salts mixtures } \\
\hline & & \multicolumn{4}{|c|}{$\begin{array}{l}\text { Broth }+\mathrm{CaCl}_{2} \\
\mu \mathrm{g} . \mathrm{CaCl}_{2} / \mathrm{ml} \text {. }\end{array}$} & \multicolumn{4}{|c|}{$\begin{array}{l}\text { Broth }+\mathrm{MgCl}_{2} \\
\mu \mathrm{g} . \mathrm{MgCl}_{2} / \mathrm{ml} .\end{array}$} & \multicolumn{4}{|c|}{$\begin{array}{l}\text { Broth }+\mathrm{SrCl}_{2} \\
\mu \mathrm{g} . \mathrm{SrCl}_{2} / \mathrm{ml} .\end{array}$} \\
\hline & & 20 & $\mathbf{5 0}$ & 100 & 200 & 20 & 50 & 100 & 200 & 20 & 50 & 100 & \\
\hline & \multicolumn{13}{|c|}{ Average burst size } \\
\hline $\mathbf{3 A}$ & 24 & 28 & 68 & 85 & 77 & 35 & 28 & 45 & 47 & 12 & 14 & 14 & 1 \\
\hline 3B & 111 & 116 & 126 & 152 & 140 & 93 & 113 & 80 & 95 & 108 & 118 & 100 & \\
\hline $\mathbf{3 C}$ & 12 & 27 & 26 & 22 & 29 & 20 & 18 & 20 & 20 & 20 & 17 & 15 & \\
\hline 6 & 44 & 66 & 122 & 90 & 106 & 45 & 54 & 46 & 64 & 52 & 42 & 54 & \\
\hline 7 & 7 & 44 & 47 & 42 & 33 & 9 & 12 & 13 & 10 & 10 & 10 & 16 & \\
\hline $42 \mathrm{E}$ & $\mathbf{3}$ & 3 & 12 & 26 & 60 & 2 & $\mathbf{3}$ & 2 & 2 & 2 & 2 & 2 & \\
\hline 47 & 20 & 43 & 56 & 100 & 68 & 24 & 22 & 20 & 12 & 18 & 21 & 19 & 1 \\
\hline $47 \mathrm{~A}$ & 29 & 24 & 50 & 61 & 63 & 16 & 20 & 21 & 22 & 23 & 28 & 22 & 3 \\
\hline 51 & 75 & 101 & 105 & 110 & 111 & 72 & 75 & 85 & 83 & 85 & 81 & 85 & \\
\hline 29 & 2 & $\mathbf{9}$ & 20 & 24 & 10 & 2 & 3 & 5 & 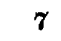 & 3 & 3 & 3 & \\
\hline $29 \mathrm{~A}$ & 6 & 41 & 92 & 91 & 30 & 6 & 6 & 15 & 29 & 4 & 14 & 14 & \\
\hline 31 & $\mathbf{1}$ & 18 & 25 & 26 & 50 & 3 & 4 & 7 & 14 & 3 & 3 & 5 & \\
\hline $31 \mathrm{~A}$ & 1 & 9 & 20 & 19 & 15 & $\mathbf{5}$ & $\mathbf{2}$ & 4 & 9 & 1 & 3 & $\mathbf{2}$ & \\
\hline $31 \mathrm{~B}$ & 10 & 20 & 45 & 71 & 102 & 3 & 3 & 6 & 12 & 2 & 4 & 8 & \\
\hline $42 \mathrm{C}$ & 0 & 0 & 14 & 18 & 15 & 0 & 0 & 0 & $\mathbf{0}$ & o & 0 & 0 & \\
\hline $42 D$ & 0 & 0 & 31 & 52 & 24 & 0 & 0 & 0 & 0 & 0 & 0 & 0 & \\
\hline 44 & 1 & 33 & 44 & 85 & 65 & 0 & 0 & 0 & 0 & 0 & o & 0 & \\
\hline $44 \mathrm{~A}$ & 3 & 16 & 37 & 60 & 61 & 4 & 8 & 9 & 8 & 4 & 4 & 6 & \\
\hline 52 & 0 & 5 & 44 & 63 & 60 & 0 & 0 & 0 & 0 & 0 & 0 & 0 & \\
\hline $52 \mathrm{~A}$ & 12 & 36 & 57 & 95 & 91 & 7 & 16 & 24 & 41 & 15 & 11 & 24 & \\
\hline
\end{tabular}

Many of the group B phages did not grow in the basal broth. Phages 42C, $42 \mathrm{D}$ and 52 disappeared partly on adsorption, but chiefly during the latent period; and the addition of at least $50 \mu \mathrm{g} . \mathrm{CaCl}_{2} / \mathrm{ml}$. was necessary before any phage multiplication took place. With these phages and with phage 44, the addition of $\mathrm{MgCl}_{2}$ or $\mathrm{SrCl}_{2}$ to broth did not prevent this disappearance of phage. Other phages (e.g. 31 and $31 \mathrm{~A}$ ) established infection in broth alone but the infected cells liberated either very little phage or none until plated. All the phages gave higher average burst sizes in the presence of $\mathrm{CaCl}_{2} ; 100 \mu \mathrm{g}$. $\mathrm{CaCl}_{2} / \mathrm{ml}$. was sufficient for maximal stimulation, with the exception of phages 31 and $31 \mathrm{~B}$ which required $200 \mu \mathrm{g}$. $\mathrm{CaCl}_{2} / \mathrm{ml}$. Some phages (e.g. $29 \mathrm{~A}, 31,31 \mathrm{~A}$, $31 \mathrm{~B}, 44 \mathrm{~A}$ and $52 \mathrm{~A}$ ) gave slight increases in average burst size when $\mathrm{MgCl}_{2}$ 
or $\mathrm{SrCl}_{2}$ was substituted for $\mathrm{CaCl}_{2}$. In no case, however, did the average burst size approach that obtained with $\mathrm{CaCl}_{2}$. It was concluded that these other cations were at best poor substitutes for $\mathrm{Ca}$ ions. Since the previous work had shown that in most cases $\mathrm{Mg}$ ion was as effective as $\mathrm{Ca}$ ion in the first step of phage adsorption, it was apparent that the stimulatory effect of $\mathrm{Ca}$ ion was concerned with some later stage of phage growth.

\section{Divalent cation activity early in the latent period}

The phages 3A and 29, representative of groups $\mathbf{A}$ and $\mathbf{B}$, were used for further study of the stage at which Ca ions were required, EDTAA $(0 \cdot 1 \%, \mathrm{w} / \mathrm{v})$ being used as a chelating agent at various times in the latent period. This concentration of the chelating agent had no effect on the infectivity of the free phages in broth at $37^{\circ}$ during $60 \mathrm{~min}$. (Table 3). The effect of the chelating

Table 3. Stability of phages $3 A$ and 29 in broth $+0 \cdot 1 \%$ ethylene diaminotetra-acetic acid (EDTAA)

\begin{tabular}{|c|c|c|c|c|}
\hline \multirow{3}{*}{$\begin{array}{l}\text { Time of } \\
\text { sampling } \\
\text { (min.) }\end{array}$} & \multicolumn{2}{|c|}{ Phage 3A } & \multicolumn{2}{|c|}{ Phage 29} \\
\hline & In broth & Broth + ED'TAA & In broth & Broth + EDTAA \\
\hline & \multicolumn{4}{|c|}{ Phage count $\left(\times 10^{-3} / \mathrm{ml}.\right)$} \\
\hline 0 & 19 & 18 & 145 & 149 \\
\hline 60 & 21 & 18 & 152 & 141 \\
\hline
\end{tabular}

agent on the growth of uninfected cultures of the propagating strains of staphylococci PS3A and 29 was examined. EDTAA $(0 \cdot 1 \%, w / v)$ was added to $3 \mathrm{hr}$. old broth cultures aerated at $37^{\circ}$; turbidities were determined at intervals thereafter. Figs. 1 and 2 show that the chelating agent had no effect on the growth rate until 50-60 min. had elapsed. Since in the experiments to be described the chelating agent was not in contact with the infected cells for more than $60 \mathrm{~min}$., and often only for 5-10 min., it was concluded that the effects obtained might be attributed to action on the hostphage complex rather than on the cells alone. When EDTAA was added to cells in broth before adding either phage, it completely inhibited adsorption, and all the phage added was recovered in supernatants when the cell + phage mixtures were centrifuged.

Phage 3A. A young broth culture of staphylococcus PS3A was infected with sufficient phage to give about 100-150 plaques $/ 0.01 \mathrm{ml}$. during the latent period. At 1, 2, 4, 6 and $20 \mathrm{~min}$. after infection, $1 \mathrm{ml}$. volumes were removed to tubes containing $0 \cdot 1 \mathrm{ml} .1 \%$ EDTAA and centrifuged (angle centrifuge). After plating samples of the supernatants to estimate unadsorbed phage, the supernatant fluids were removed, the cells resuspended in $1 \mathrm{ml}$. broth and held in an ice + water bath until plated, as a precaution against phage release before plating. Table 4 shows that, compared with the control which was centrifuged at 6 min., EDTAA added at 1-6 min. markedly decreased the number of infected cells which could be recovered. The maximal effect occurred when the 
chelating agent was added at $2 \mathrm{~min} ; 89 \%$ of the adsorbed phage was then inactivated. When EDTAA was added at $20 \mathrm{~min}$. there was little or no inactivation of phage.

Subsequent experiments confirmed that the period 2-3 min. after addition of the phage was the critical time at which the chelating agent had its maximal inactivating effect. Ten minutes after infection the phage + host complex

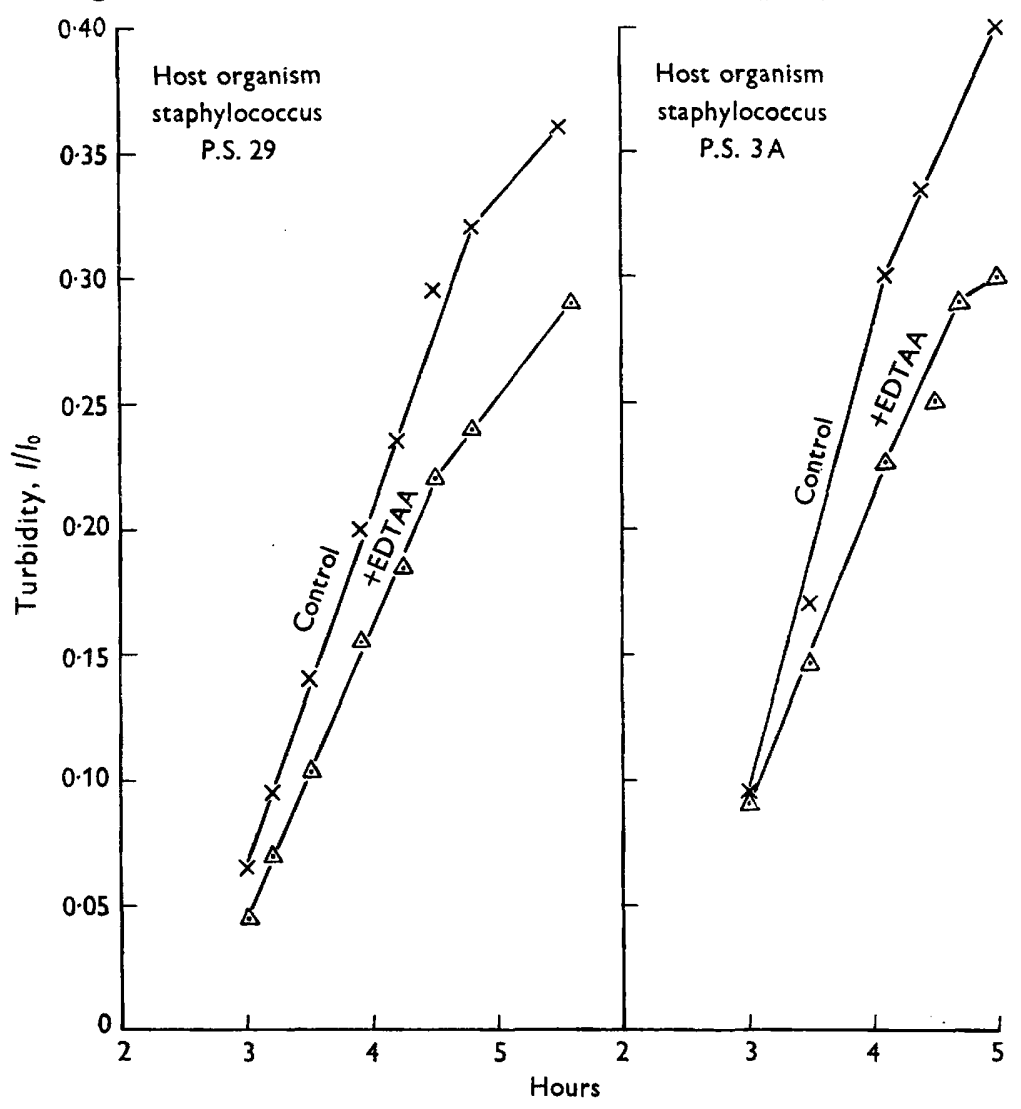

Fig. 1.

Fig. 2.

Figs. 1 and 2. The effect of EDTAA $(0 \cdot 1 \%, w / v)$ added at $3 \mathrm{hr}$. on the growth in broth of propagating strains of staphylococci no. 29 and $3 \mathrm{~A}$.

reached a stage where the removal of divalent cations had no effect on the ability of the infected cells to register as infective centres when plated. This critical period might be called the period of vulnerability. The recovery of some infective centres when EDTAA was added at 1-4 min. indicated that already at these times a few particles had passed through this vulnerable period. The period of vulnerability for any individual particle might be of very short duration and the later in the latent period that the chelating agent was added, the greater the number of particles that would have been adsorbed and have passed this point (see Table 4). In these experiments, the chelating agent was in contact with the cells for at least $8 \mathrm{~min}$. before it was removed in the 
supernatant fluid on centrifuging. In order to ascertain the minimum length of time of contact necessary for inactivation of the adsorbed phage, the action of the chelating agent was halted by dilution, for $0.01 \%$ EDTAA had no inactivating effect. The cells received ten times the previous amount of phage, EDTAA was added $2 \mathrm{~min}$. later and, at intervals, $0.1 \mathrm{ml}$. samples were diluted in $0.9 \mathrm{ml}$. broth in tubes held in an ice + water bath to prevent further phage

Table 4. Effect of time of addition of $0 \cdot 1 \%$ EDTAA on recovery of adsorbed phage from cells infected with phage $3 \mathrm{~A}$

\begin{tabular}{|c|c|c|c|c|c|c|}
\hline Tube & $\begin{array}{c}\text { EDTAA } \\
\text { added at } \\
(\min .)\end{array}$ & $\begin{array}{l}\text { Phage } \\
\text { added } \\
(a)\end{array}$ & $\begin{array}{c}\text { Phage in } \\
\text { supernatant } \\
(b)\end{array}$ & $\begin{array}{c}\text { Phage } \\
\text { adsorbed } \\
\qquad(a-b)\end{array}$ & $\begin{array}{l}\text { Phage } \\
\text { recovered } \\
\text { in cells }\end{array}$ & $\begin{array}{c}\% \text { of } \\
\text { adsorbed } \\
\text { phage } \\
\text { recovered }\end{array}$ \\
\hline $\mathbf{1}$ & $\begin{array}{c}\text { Control no } \\
\text { EDTAA }\end{array}$ & 145 & 45 & 100 & 100 & 100 \\
\hline 2 & 1 & 145 & 94 & 51 & 14 & 27 \\
\hline $\mathbf{3}$ & 2 & 145 & 80 & 65 & 7 & 11 \\
\hline 4 & 4 & 145 & 68 & 77 & 32 & 42 \\
\hline 5 & 6 & 145 & 50 & 95 & 49 & 53 \\
\hline 6 & 20 & 145 & 13 & 132 & 118 & 90 \\
\hline \multicolumn{7}{|c|}{ Phage $/ 0.01 \mathrm{ml}$; mean of 4 replicates } \\
\hline
\end{tabular}

Table 5. The effect of dilution into broth of phage $\mathbf{3} A+$ cell mixtures to which $0.1 \%$ ethylene diamino tetra-acetic acid (EDTAA) was added

No EDTAA was added to tube 1 ; EDTAA was added to tubes $2-6$ at 2 min. after the addition of phage.

\begin{tabular}{|c|c|c|c|c|c|}
\hline Tube & $\begin{array}{l}\text { Time of } \\
\text { dilution }\end{array}$ & $\begin{array}{l}\text { Time of } \\
\text { contact with } \\
\text { EDTAA }\end{array}$ & $\begin{array}{c}\text { Phage } \\
\text { adsorbed/ } \\
0.01 \mathrm{ml} .\end{array}$ & $\begin{array}{l}\text { Phage } \\
\text { in cells }\end{array}$ & $\begin{array}{c}\text { Phage } \\
\text { inactivated }\end{array}$ \\
\hline 1 & $1 \mathrm{~min} .55 \mathrm{sec}$. & 一 & 82 & 82 & 0 \\
\hline 2 & $2 \mathrm{~min} .50 \mathrm{sec}$. & 50 sec. & 82 & 42 & 40 \\
\hline $\mathbf{3}$ & $3 \mathrm{~min}$. & 60 sec. & 82 & 46 & 36 \\
\hline 4 & $3 \mathrm{~min} .30 \mathrm{sec}$ & 90 sec. & 82 & 41 & 41 \\
\hline 5 & $4 \mathrm{~min}$. & 120 sec. & 82 & 42 & 40 \\
\hline 6 & *4 min. 10 sec. & $>8 \mathrm{~min}$. & 82 & 32 & 50 \\
\hline
\end{tabular}

adsorption. The samples after chilling were centrifuged and plated as before. Table 5 shows that approximately $50 \%$ of the phage adsorbed to the cells at 2 min. was inactivated by 50 sec. contact with the chelating agent. Tube 6 , in which the mixture was diluted in broth $+0 \cdot 1 \%$ EDTAA, served as a control; it indicated that there was little if any reversal of the phage inactivation on dilution into broth. A very short period of exposure to the chelating agent was therefore sufficient for irreversible inactivation of adsorbed phage.

Infection with lytic phage normally results in death of the cell; EDTAA $(0.1 \%)$ added to cells 3 min. after infection protected at least half the cells from this lethal action. Table 6 shows the results of two experiments with different phage/cell ratios in which viable cell counts were made $10 \mathrm{~min}$. after infection, the centrifuged infected cells being diluted in broth which contained phage antiserum. 
Table 6. The protection of cells infected with phage $\mathbf{3} A$ by the addition of ethylene diamino tetra-acetic acid (EDTAA) 3 min. after infection

\begin{tabular}{|c|c|c|c|c|}
\hline Treatment & Cells/ml. & $\begin{array}{l}\text { Phage/cell } \\
\text { adsorbed }\end{array}$ & $\begin{array}{c}\text { Viable } \\
\text { cells/ml. }\end{array}$ & $\begin{array}{c}\text { Cells } \\
\text { killed } \\
(\%)\end{array}$ \\
\hline $0.1 \%$ EDTAA & $5 \times 10^{7}$ & 3 & $2.4 \times 10^{7}$ & 50 \\
\hline No EDTAA & $5 \times 10^{7}$ & 3 & $1.5 \times 10^{6}$ & 97 \\
\hline $0.1 \%$ EDTAA & $7 \times 10^{7}$ & 0.7 & $5.4 \times 10^{7}$ & 23 \\
\hline No EDTAA & $7 \times 10^{7}$ & $0 \cdot 7$ & $3.5 \times 10^{7}$ & 50 \\
\hline
\end{tabular}

Phage 29. In one particular batch of broth phage 29 adsorbed slowly on to its own propagating strain. Also, very little adsorbed phage could be recovered as infective centres, thus giving results resembling phage $3 \mathrm{~A}$-infected cells + EDTAA. The addition of $\mathrm{CaCl}_{2}$ to the cells before adding phage resulted in more efficient cell infection. Table 7 indicates that in this broth the phage had a threshold requirement of added $\mathrm{CaCl}_{2}$ which was between 100 and $200 \mu \mathrm{g} . / \mathrm{ml}$., since in unsupplemented broth and in broth $+100 \mu \mathrm{g}$. $\mathrm{CaCl}_{2} / \mathrm{ml}$., only 18 and $19 \%$ respectively of the adsorbed phage was recovered.

Table 7. Infection of staphylococcus PS29 with phage 29 in broth and in broth $+\mathrm{CaCl}_{2}$

Each tube contained phage + cells and the amount of $\mathrm{CaCl}_{2}$ indicated.

$\begin{array}{ccccc}\text { Tube } & \begin{array}{c}\text { Amount } \\ \text { of } \mathrm{CaCl}_{\mathbf{2}} \\ (\mu \mathrm{g} . / \mathrm{ml} .)\end{array} & \begin{array}{c}\text { Phage } \\ \text { adsorbed }\end{array} & \begin{array}{c}\text { Phage in } \\ \text { cells }\end{array} & \begin{array}{c}\text { Adsorbed } \\ \text { phage lost } \\ (\%)\end{array} \\ 1 & - & 61 & 11 & 82 \\ 2 & 100 & 68 & 13 & 81 \\ 3 & 200 & 66 & 46 & 30 \\ 4 & 300 & 68 & 39 & 43 \\ 5 & 400 & 65 & 40 & 38\end{array}$

Phage/0.01 ml.; mean of 4 replicates

The substitution for staphylococcus PS 29 of another strain R5310, resulted in more rapid adsorption of phage, but the cation requirements were the same and even in $200 \mu \mathrm{g} . \mathrm{CaCl}_{2} / \mathrm{ml}$. only $42 \%$ of the adsorbed phage was recovered. Nevertheless, when infection was established in these suspensions of cells + $\mathrm{CaCl}_{2}$ and EDTAA added 2 and 6 min. later, inactivation of adsorbed phage could be demonstrated (Table 8 ).

Table 8. Effect of time of addition of EDTAA on recovery of adsorbed phage from cells of staphylococcus $R 5310$ infected by phage 29

Each tube contained phage + staphylococci and except in Tube $1 \mathrm{CaCl}_{2}, 200 \mu \mathrm{g} . / \mathrm{ml}$. EDTAA (to 0.1\%) was added at the times shown.

\begin{tabular}{|c|c|c|c|c|}
\hline Tube & $\begin{array}{l}\text { EDTAA } \\
\text { added }\end{array}$ & $\begin{array}{c}\text { Phage } \\
\text { absorbed }\end{array}$ & $\begin{array}{l}\text { Phage } \\
\text { in cells }\end{array}$ & $\begin{array}{c}\text { Adsorbed } \\
\text { phage lost } \\
(\%)\end{array}$ \\
\hline $\mathbf{I}$ & Nil & 109 & 9 & 92 \\
\hline 2 & Nil & 108 & 63 & 58 \\
\hline 3 & At 2 min. & 106 & 22 & 79 \\
\hline 4 & At 6 min. & 115 & 31 & 73 \\
\hline 5 & At $10 \mathrm{~min}$. & 124 & 54 & 61 \\
\hline 6 & At $20 \mathrm{~min}$. & 137 & 74 & 62 \\
\hline
\end{tabular}


To summarize, shortly after adsorption, phages $3 \mathrm{~A}$ and 29 pass through a period during which they can be inactivated by the addition of a chelating agent. This inactivation is rapid and irreversible and protects the cell from the lethal action of the phage. A reasonable hypothesis to explain these findings is that in the absence of divalent cations phage DNA cannot penetrate the cell. The divalent cations may therefore be essential to the process of penetration.

\section{Effect of divalent cations in penetration}

The experiment with a chelating agent in broth did not distinguish between a specific $\mathrm{Ca}$ ion effect and one due to divalent cations. The phenomenon of penetration was therefore examined by another method. When staphylococci are grown in citrated broth and resuspended in distilled water to which appropriate concentrations of cations have been added, the cocci adsorb phage which can be recovered as infective centres when the plating is done within $30 \mathrm{~min}$. of infection. It can be argued that, under these conditions, phage adsorption had resulted in the first step only and that the later steps proceeded when the cells were transferred to the plating medium which contained adequate amounts of $\mathrm{Ca}$ ion. When, however, differences in the activity of various cations can be demonstrated under such conditions, then it may be assumed that penetration has taken place. Such differences were found. In experiments of this kind complete recovery of added phage was rare, partly because of inactivation of the free phage in distilled water and partly because of a proportion of abortive adsorptions. Nevertheless, the method can be used to compare the relative activity of equivalent amounts of cations.

Young cells grown in $\mathbf{0 . 5} \%(\mathrm{w} / \mathrm{v}) \mathrm{Na}$ citrate broth were centrifuged and resuspended in distilled water. Samples $(0.8 \mathrm{ml}$.) were distributed into tubes containing $0.1 \mathrm{ml}$. water or appropriate concentrations of $\mathrm{CaCl}_{2}, \mathrm{MgCl}_{2}$ or $\mathrm{SrCl}_{2} ; 0 \cdot 1 \mathrm{ml}$. volumes of phage suspension (diluted in water) were then added. After 10 min. adsorption the tubes were centrifuged, the supernatant fluid, and the cells resuspended in water were plated.

Before penetration can occur the first step of adsorption must take place. This can be measured by the disappearance of free phage from the supernatant but is complicated by the fact that some phages are unstable in the salt solutions in absence of cells and it is not always possible to be certain whether their disappearance in the salt + cell suspensions is due to adsorption and inactivation or to inactivation while unadsorbed. In a previous paper (Rountree, 1951), basing evidence for lack of adsorption on the similarity between amounts of free phage in salt solutions and in salt solutions + cells, it was concluded that phages 7 and $42 \mathrm{E}$ had specific $\mathrm{Ca}$ ion requirements for adsorption. The present results, however, indicate that small amounts of phage adsorb and penetrate in the presence of $\mathbf{M g}$ or $\mathrm{Sr}$ ion and small amounts of $42 \mathrm{E}$ in the presence of $\mathrm{Mg}$ but none in the presence of $\mathrm{Sr}$ ion.

The phages fell into four groups according to the relative activity of the three cations (Table 9). All the phages which showed penetration in $\mathrm{SrCl}_{2}$ belonged to group $\mathbf{A}$. On the other hand, the group $\mathrm{B}$ phages showed no $\mathrm{Sr}$ 
activity and in three cases, comparatively little $\mathrm{Mg}$ activity. This lack of $\mathrm{Mg}$ or $\mathrm{Sr}$ activity was not due to failure of adsorption, since the free phages were relatively stable in these salt solutions in the absence of cells. Phage $42 \mathrm{E}$, which is group A serologically, was aberrant in its behaviour.

Table 9. Relative activity of $\mathrm{Ca}, \mathrm{Mg}$ and $\mathrm{Sr}$ in penetration of staphylococcal phages

$++=$ cations equally active; $\pm=$ cations partially active compared with $\mathrm{Ca} ;-=$ no activity.

\begin{tabular}{cccl} 
Ca & $\begin{array}{l}\text { Mg } \\
\text { Relative activity }\end{array}$ & \multicolumn{1}{c}{ Phages } \\
$\overbrace{++}$ & ++ & ++ & $\mathbf{3 B}, 6,7,47$ \\
++ & ++ & \pm & $\mathbf{3 A}, \mathbf{3 C}, 47 \mathrm{~A}, 51$ \\
++ & ++ & - & $\mathbf{2 9}, \mathbf{2 9 A}, \mathbf{3 1 A}, \mathbf{3 1} \mathrm{B}, 42 \mathrm{D}, 52 \mathrm{~A}$ \\
++ & \pm & - & $\mathbf{3 1}, 42 \mathrm{E}, 44,52$
\end{tabular}

The results indicate that, save with phages $31,42 \mathrm{E}, 44$ and 52, no specific Ca ion effect was demonstrated for phage penetration and that even in the exceptions there was partial activity with $\mathrm{Mg}$ ion. The stimulatory effect of $\mathrm{Ca}$ ion must therefore occur at a later stage in phage growth.

\section{The effect of calcium towards the end of the latent period}

Since the addition of $\mathrm{CaCl}_{2}$ to broth increased the average burst size with all the phages examined and in some cases converted an unsuitable broth to one which gave a good yield of phage, a chelating agent added to the infected cells after penetration has occurred should decrease the average burst size. Na citrate was found to have this effect, but owing to its inactivation of free phage, doubt existed as to the point in the growth cycle at which it acted. The effect of $0.1 \%$ EDTAA on the average burst size and growth curves of phages $3 \mathrm{~A}$ and 29 was therefore investigated. This concentration of EDTAA $(\mathbf{0} \cdot \mathbf{1} \%)$ did not completely inhibit phage production but did cause a marked decrease in average burst size. Figs. 3 and 4 show that this depressive effect occurred whether the chelating agent was added relatively early or late in the latent period. Phage $3 \mathrm{~A}$ showed a similar degree of decrease in phage yield/cell, whether the EDTAA was added at 20, 30, 40 or 50 min. after infection: Similarly, phage 29 gave lower average burst sizes when EDTAA was added at 10 or $50 \mathrm{~min}$. In the latter case, phage release was already occurring when the chelating agent was added. This depressive action of EDTAA could be partially reversed by the addition of $\mathrm{CaCl}_{2}$ to the infected cells, provided this was done before phage release was completed (Table 10). It was concluded that in these phages the specific $\mathrm{Ca}$ ion requirements were concerned with a very late step in phage synthesis.

The failure of phages of group B, e.g. 42C, 42D, 44 and 52, to produce phage in the basal broth or broth $+\mathrm{MgCl}_{2}$ was not due solely to failure of penetration. When $\mathrm{Mg}$ ions were adequate for penetration, successive platings of the infected cells showed their gradual failure to register as infective centres. It 
would seem therefore that, in the absence of adequate amounts of $\mathrm{Ca}$ ion these phage + cell complexes gradually lost their ability to complete a step in phage multiplication. The present data do not, however, allow a distinction between an early and late need for $\mathrm{Ca}$ ion in these phages.

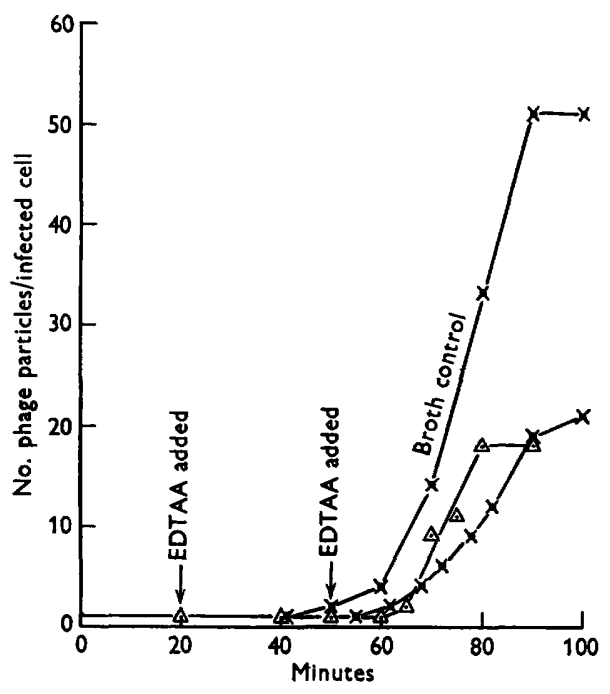

Fig. 3.

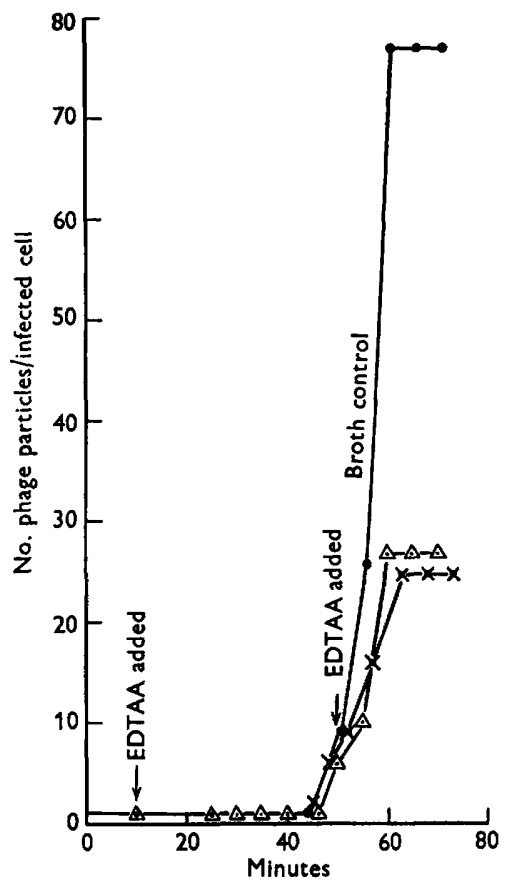

Fig. 4.

Fig. 3. The effect of EDTAA (0.1\%, w/v) on the one-step growth curve in broth of phage $3 A$. $\triangle-\triangle=$ EDTAA added at $20 \mathrm{~min}$. $\quad x-x-x=$ EDTAA added at $50 \mathrm{~min}$.

Fig. 4. The effect of EDTAA $(0 \cdot 1 \%, w / v)$ on the growth curve in broth of phage 29 . $\triangle-\Delta=$ EDTAA added at $10 \mathrm{~min}$; $x-x-x=$ EDTAA added at $50 \mathrm{~min}$.

Table 10. Partial annulment by $\mathrm{CaCl}_{2}$ of the effect of EDT $A A$ on the average burst size of phage $\mathbf{3} \mathbf{A}$

Tube

no.

Contents of tube

$\begin{gathered}\text { Average } \\ \text { burst } \\ \text { size }\end{gathered}$
42
70
10
40
20
22

\section{DISCUSSION}

From the present results and those previously reported, a general outline of the role of divalent cations in the growth of staphylococcal typing phages may be suggested. It should be understood, however, that the quantitative 
details vary from phage to phage. Adsorption of the phages to their host cells requires divalent cations and can be inhibited by suitable chelating agents. Following adsorption, the phage particle passes through a short period during which it can be irreversibly inactivated by the removal of divalent cations from the medium. Although there is no direct evidence, it seems reasonable to assume that this inactivation is due to the abortive separation of phage protein and deoxyribonucleic acid at the cell surface and the inability of the deoxyribonucleic acid to penetrate the cell in the absence of divalent cations. With the possible exception of phage $42 \mathrm{E}$, there is no evidence of any specific $\mathrm{Ca}$ ion requirements in these steps. There is, however, evidence of a correlation between antigenic structure and cation requirement since the group B phages are unable to use $\mathrm{Sr}$ ion for penetration.

After this 'vulnerable' period has passed, the phage material is no longer inactivated by the chelating agent EDTAA and infected cells treated with this substance from $10 \mathrm{~min}$. onward in the latent period will register as infective centres when plated. There is, however, a specific calcium requirement late in the latent period. This is shown by the increase in average phage yield/ cell in increasing concentrations of $\mathrm{Ca}$ ion and in the depression in yield in the presence of a chelating agent. Particularly with the group A phages, the amount of $\mathrm{CaCl}_{2}$ which stimulates phage yield is much greater than that required for adsorption or penetration; for example, phage $3 \mathrm{~A}$ requires $10 \mu \mathrm{g}$. $\mathrm{CaCl}_{2} / \mathrm{ml}$. for adsorption and $100 \mu \mathrm{g} . \mathrm{CaCl}_{2} / \mathrm{ml}$. for maximal stimulation. In a few cases, some stimulation of yield can be obtained with $\mathrm{Mg}$ or $\mathrm{Sr}$ but neither cation is as effective as an equivalent amount of $\mathrm{Ca}$ and generally no activity is found.

The results do not exclude the possibility that $\mathrm{Ca}$ ion is also required specifically for some process in phage synthesis which immediately follows penetration, as suggested for other phages by Fildes (1953); but they do indicate the importance of $\mathrm{Ca}$ ion in the final stages of phage multiplication. It is unlikely that the effect of EDTAA is a direct one on the metabolism of the host cells since in some experiments in which a decrease in phage yield was obtained the chelating agent was in contact with the cells for only 5-10 min. before they were plated. There is a possibility that the depressive effect of the chelating agent was due to its direct inactivation of completed phage particles not yet liberated from the cell. Since, however, free phage particles after liberation were not affected by the concentration of chelating agent used, this seems unlikely. It is possible that the effect of the chelating agent is an indirect one in making $\mathrm{Ca}$ unavailable to not yet completed phage particles or to some enzyme or enzymes concerned in phage synthesis. The stabilizing effect of $\mathrm{Ca}$ ions on various proteins and enzymes is a well-recognized biological phenomenon and their activity in the synthesis of the staphylococcal phages may be of a similar nature.

This work was supported by a grant from the Australian National Health and Medical Research Council. Miss Shirley Garvin Smith gave technical assistance in a portion of the investigation. 


\section{REFERENCES}

Adams, M. H. (1949). The calcium requirement of coli phage T5. J. Immunol. 62, 505.

Beumer, J. \& Beumer-Jochmans, M. P. (1951). Les exigences en calcium du phage de Lisbonne. Ann. Inst. Pasteur, 81, 489.

Delbrück, (1948). Biochemical mutants of bacterial viruses. J. Bact. 56, 1.

Fildes, P. (1953). Factors affecting the multiplication of bacteriophage. VI Congr. int. Microbiol. Symp. Mutation and Growth Factors, p. 184.

Fildes, P., KAY, D. \& JoKLIK, W. K. (1953). Divalent metals in phage production. Symp. Soc. gen. Microbiol. $2,194$.

Luria, S. E. \& Steiner, D. L. (1954). The role of calcium in the penetration of bacteriophage T5 into its host. J. Bact. 67, 635.

Potter, N. N. \& Nelson, F. E. (1953). Role of calcium and related ions in proliferation of lactic streptococcus bacteriophage. J. Bact. 66, 508.

Puck, T. T. (1953). The first steps of virus invasion. Cold Spr. Harb. Symp. quant. Biol. 18, 149.

Rountree, P. M. (1949). The serological differentiation of staphylococcal bacteriophages. J. gen. Microbiol. 3, 164.

Rountree, P. M. (1951). The role of certain electrolytes in the adsorption of staphylococcal bacteriophages. J. gen. Microbiol. 5, 673.

Wrlliams Smith, H. (1948). Calcium-deficient media: their effect on phage action. Nature, Lond. 161, 397.

Wilson, G. S. \& Atkinson, J. D. (1945). Typing of staphylococci by the bacteriophage method. Lancet, i, 647 .

(Received 11 October 1954) 